\title{
Is (Translational) \\ Hermeneutics of any Use for the (Cognitive) Analysis of Translation Products? ${ }^{24}$
}

\begin{abstract}
Traditionally, translation scholars have analyzed translation products by putting emphasis on the purely linguistic phenomena of a target text as related to a source text. However, the author of this paper claims that in order to analyze a translation product in all its facets, it is necessary to add a phenomenology-oriented approach to it, along with the accounts of the translators who translated the text in question. The aim of the article is to present how a standard way of the analysis of a translation product, including a cognitive one, might be enriched by considering the phenomenological and hermeneutic points of view. By analyzing a fragment of a women's fiction novel, the author tries to demonstrate how a translation critic might evaluate translation products in order to gain insights into how translators go through the translation process. As well as that, the paper aims to refrain from regarding the act of translation and translation products as purely 'objective' phenomena but more on stressing the need for taking into account the subjectivity and inter-subjectivity of the act of translation as embedded in the relationship between a text and its readers (translators).
\end{abstract}

Keywords: translational hermeneutics; translation product; translation process; Radegundis Stolze; phenomenology.

\section{Introduction}

The inspiration for writing this article was, first and foremost, Ludwig Wittgenstein's words of 'language in use' as well as his concept of language games (1953: \$7). According to the philosopher, language is composed of a set of devices used in order to participate actively in different kinds of social activities. Thus the meaning of a particular word should be based not on orthographic

24 The title of the article refers to, and was, to some extent, inspired by, Elżbieta Tabakowska's text, entitled Is (Cognitive) Linguistics of any Use for (Literary) Translation? (2000: 83-95). In many of the author's texts, one may find the description of precise tools which a translation critic might use in order to explain and justify his/her strategies and the way of interpreting texts. Tabakowska opted for the search of some specific grammatical markers symbolizing semantic contents of the message being translated. Similarly, the author of this article entitled Is (Translational) Hermeneutics of any Use for (Cognitive) Analysis of Translation Products? attempts to demonstrate that the useful tools of translational hermeneutics and factors such as translator's subjectivity, as well as his/her motivations and translational decisions, might be used in order to gain a broader picture of the phenomenon of the act of translation. 
principles, but rather on its functional and social dimension (see also Nida 1964). Likewise, due to the high unpredictability of both linguistic and translational phenomena, the act of translation could as well be defined as 'translation in use' and 'translation games. ${ }^{25}$ Accordingly, the latter term should be defined as a concept concerning particular translation strategies that are adopted by a translator as well as of translational decisions made with relation to the translational process. Building on Wittgenstein's philosophy of language, the author of the paper claims that translation (perceived either as a text or as a process) should not be interpreted in terms of an ontological entity but rather as a specific process of creating something new, a means of communication, and a way of understanding. Similarly, scientific writing on the act of translation, including translation criticism, constitutes a specific activity through which the act of translation acquires a new meaning. Therefore, it is impossible to speak of any translation rules that a translator obeys in order to produce a successful translation. Rather, one should attempt to describe 'translation in use' as being determined by the cultural and historical context in which both a particular text and a particular translator occur.

Paraphrasing Stolze (2011: 27), it might be stated that translation products are invariably characterized by the individuality of both the respective situation in which a particular translation is produced and a translator's competence, his/her knowledge of the world, life and professional experience, and the interpretation of a text. As Wilss (1996: 99) claimed, translation is a process based on the strategy adopted by an individual, according to a particular situation in which the process occurs. With regard to the above, it seems reasonable to take into consideration the element of subjectivity in the translation process, so often neglected or even undermined by contemporary translation scholars. It is worth citing Stolze (2011: 34), who is of the opinion that subjectivity should be perceived as an integral element of not only the translational process but also, broadly speaking, translation research:

Subjectivity in human activity is an ontological given, and it should therefore be reflected upon and integrated into the model. This creates responsibility. And individual variance of texts and situations is an offspring of it, equally not to be eliminated in the studies. In our view, the translator's approach is not a "behavior" but an attitude and outlook towards texts leading to a strategical action.

Nevertheless, a considerable number of contemporary writings concerning the quality and nature of translation products (including translation criticism), even those attempted from a cognitive point of view (see Tabakowska 2015), try to demonstrate, albeit in an indirect way, that a translation product might be objectively evaluated on the basis of established linguistic or grammatical parameters, which are to serve as 'objective' criteria helping a translation critic in the process of evaluating the quality of the final product and the changes that have been made by a translator. However, the author of the paper argues, from a phenomenological point of view, that the analysis of translation products, without taking into consideration the intersubjective and subjective ele-

25 To the best of the author's knowledge, so far, nobody has used the term in a research paper. 
ments of the translational process, is by no means an adequate way of evaluating the activity of a translator. Therefore, it is necessary to consider not only the text itself and its inner (grammatical) structure' but also the position of both the text and the translator producing a translation. The significant element is the relationship between the text and the translator as a creative reader decoding the meaning of the source message. The view is also clearly expressed by Iser (1978: 108-109), who described the nature of the text in the following terms:

In our attempts to describe the intersubjective structure of the process through which a text is transferred and translated, our first problem is the fact that the whole text can never be perceived at any one time. In this respect it differs from given objects, which can generally be viewed or at least conceived as a whole. The 'object' of the text can only be imagined by way of different consecutive phases of reading. We always stand outside the given object, whereas we are situated inside the literary text. The relation between text and reader is therefore quite different from that between object and observer: instead of a subject-object relationship, there is a moving viewpoint which travels along inside that which it has to apprehend.

Texts do not constitute objects whose existence and meaning might be verified and proven by empirical means, and although they contain 'things' which exist in the world that are often described as 'real' or 'objective', they might be perceived only by taking into account the context in which they are placed (see Iser 1978: 107-134). Furthermore, according to the phenomenological point of view, the meaning of a text is formed by a reader who, in the consecutive phases of the process of reading, creates the entirety of various senses, in the helical movement of hermeneutical interpretation based on his/her previous knowledge and experience as well as on the expectations which influence the way a text is perceived. In a similar vein, a translation scholar, instead of pointing to translation errors distinguished on the basis of questionable linguistic criteria (without reflecting upon the social and historical setting in which a given text has arisen), should rather ask 'why' a certain phenomenon has taken place and what implications it might have for the perception of a specific translation in a given community. It should be added at this point that it does not make much sense if a scholar attempts to analyze a published target text without taking into account the nature of the publishing process and all possible changes that could have been made by a proofreader, and not by the translator himself/herself.

In what follows the paradigm of translational hermeneutics is presented. The next sections of this article are dedicated to the presentation of the hermeneutical dimensions of the translation production analysis as developed by Stolze (2011), which might serve as the starting-point for further discussion of the analysis of both the source and the target text. The author of this paper attempts to determine to which extent and in what way the categories developed by Stolze might be used in a critical evaluation of a translator's rendering. The third part of the paper complements the second part in that it is devoted to the presentation of two translators' accounts, who were instructed to translate a sample of a source text and to answer retrospective questions concerning the translation process in which they had participated. The main objective of the article is to show 
that in any analysis of translation products it is worthwhile taking into consideration the aspect of both subjectivity and inter-subjectivity as they cover the realm of the translation processes.

\section{Translational Hermeneutics Paradigm}

Although hermeneutical reflection on the phenomenon of translation has been present both in the philosophy of language and in translation studies for many years now, it may be observed that since 2009, translational hermeneutics has developed rapidly as a relatively new sub-discipline of translation studies. It is now propagated mainly by Radegundis Stolze, Larisa Cercel and John Stanley - German scholars interested in the hermeneutical theory of translation. There are at least three visible ways in which translational hermeneutics is achieving prominence nowadays: 1) a proliferation of journal articles and books pertaining to the main tenets of hermeneutics, including the act of translation; 2) a proliferation of scientific events, namely conferences dedicated either exclusively to the relationship between hermeneutics and translation studies or to hermeneutics as a theory of interpretation and understanding, including associations with themes such as the role of a translator, the nature of the phenomenon of translation, and the interconnection of translation and linguistic issues. Naturally, the sub-discipline is by no means unidirectional (Cercel, Stolze, Stanley 2015: 22-24):

In the $20^{\text {th }}$ century translational hermeneutics received a dramatic development by its expansion into three different disciplines. In philosophy, the topics of translation have a special standing in the works of Martin Heidegger, Hans-Georg Gadamer and Paul Ricœur. This is now documented in the growing amount of secondary literature on that subject. The interest for translation stands in close connection with the primary linguistic nature of philosophical debates at the time...

In literary studies the hermeneutical approach is present mainly with George Steiner's After Babel (1975) and Friedmar Apel's Sprachbewegung (The movement of language, 1982). Their theoretical considerations, of course, are limited to the translation of literary texts. Those dealing with the subject of translation in literary studies focus on the historical and dynamic dimension of the act of translating...

Fritz Paepcke, who was strongly influenced by Heidegger and above all by Gadamer, was one of the first scholars to advocate the hermeneutical approach in TS...

The hermeneutic theory of translation centers on the personalization of the act of translation, which is perceived as a dynamic task that might be divided into two main stages: translational reading (based on a deep understanding of the source text) and translational writing (concentrated on the principles of rhetorics, the proper usage of native language as well as the use of adequate strategies). The most important concepts of translational hermeneutics are subjectivity, historicity, phenomenology, the process character of translation, the holistic nature, and a critical reflection (see Stolze 2011: 45-67; Cercel, Stolze, Stanley 2015: 26-28). Those concepts have been extensively 
used by Stolze; they constitute the basis on which the author focused when creating her own hermeneutical translation theory. ${ }^{26}$

Although translational hermeneutics is a relatively new sub-discipline of translation studies, it is starting to develop rapidly across the globe. It encompasses a wide range of theoretical and methodological approaches, building on philosophical concerns for an ontological category of 'translation.' The tenets of translational hermeneutics might be used for the evaluation of both translation products and translation processes.

\section{Hermeneutical Orientation in the World of the Source and Target Texts}

In what follows, the hermeneutical analysis of the source text as related to the renderings in the target language is presented. A relatively short fragment of a novel entitled The Ballroom's Café - written by a contemporary Irish author Ann O'Loughlin and translated into Polish by two professional Polish translators - serves as a point of reference for the discussion of hermeneutical factors determining the way the target text might be evaluated. The source sample is given below:

\section{Rathsorney, Co. Wicklow, March 2008}

'You have four more weeks, Miss O'Callaghan. It is the way things are now; the bosses in Dublin want to see some effort towards paying the loan. Otherwise we are going to have to take steps to get our money back.'

Bank manager Peter O'Doherty leaned back on his swivel chair. Raising her head sufficiently to look him straight in the eye, Ella O'Callaghan spoke in a slow, firm voice.

'What do you propose I do: prostitute myself, Mr O'Doherty?'

'Miss O'Callaghan, there is no need to be like that.'

'There is no need to threaten to push me out of my home. I won't let you. Roscarbury Hall is my life. I won't let you take it.'

'Maybe there is something you can sell off to get in some money?'

'Like my extensive jewel collection, I suppose.'

Peter O'Doherty jumped to his feet, impatiently fingering his bunch of keys.

26 It should be noted that the concepts which characterize translational hermeneutics are, to some extent, compliant with the tenets of cognitive linguistics (see Stolze 2011: 64-67; Gallagher 2004: 162-174). 
'Go home, think about it. Come back next week with some sort of plan for repayment.'

He put out his hand to Ella, but she ignored it.

'In all my prayerful life, I have never felt so crucified. I will die before I move out of Roscarbury Hall.'

If O'Doherty intended to answer, she did not give him a chance, sweeping out of his office, banging the door. What did he care about Roscarbury, how the old house folded around them in bad times, how it was the only place where she felt safe? The rooms were so cold in winter you could see your breath, the stairs to the attic creaked like a banshee, and the chill winds rattled the window latches in a din of constant tapping. The parkland dipped and rolled away to the lake, so it was impossible for Sheehy the farmer to get his hay cutter properly across it; the rills silted up every year, long after the cherry blossom flowers had gone dark brown and sodden and the oak and old horse chestnut trees had shed their leaves.

Roscarbury existed for the worn days of summer sun, when warm air lingered in the house and the hens had to be hunted from the open back door. It was the starlings gathering and chattering on the wonky television aerial strapped to the first chimney that woke Ella every morning. The crows and pigeons in the fir trees destroyed the stone slabs around the fountain and she had to scrub it down once a month. The overgrown kitchen garden gave fruit for enough tarts through the summer months and luscious pears in a hot spell. Ella could never leave Roscarbury: the mists of the past shrouding the old house webbed around her, keeping her calm.

Below the two translations, which were done by professional translators, both members of the Polish Association of Literary Translation, are presented. The subjects were instructed to translate the above sample and then to comment on certain aspects of translation process, including translation strategies, translation decisions as well as translation tools.

\begin{tabular}{|c|c|}
\hline The first version of the translation & The second version of the translation \\
\hline Rathsorney, hrab. Wicklow, marzec 2008 & Rathsorney, hrabstwo Wicklow, marzec 2008 \\
\hline $\begin{array}{l}\text { - Ma pani jeszcze cztery tygodnie, panno O’Callaghan. } \\
\text { Tak to obecnie wygląda; szefostwo w Dublinie chce } \\
\text { widzieć jakieś starania w sprawie spłaty pożyczki. W } \\
\text { przeciwnym razie będziemy zmuszeni podjąć stosowne } \\
\text { kroki, aby odzyskać naszą należność. }\end{array}$ & $\begin{array}{l}\text { - Daję pani cztery tygodnie, panno O’Callaghan. Oto, } \\
\text { jak wygląda sytuacja: moi zwierzchnicy w Dublinie } \\
\text { chcą zobaczyć, że czyni pani starania w kierunku spłaty } \\
\text { pożyczki. Inaczej podejmiemy odpowiednie kroki w } \\
\text { celu odzyskania pieniędzy. }\end{array}$ \\
\hline Dyrektor banku Peter O’Doherty rozsiadł się wygodniej & Dyrektor banku Peter O’Doherty odchylił się na oparcie \\
\hline w swoim fotelu obrotowym. Ella O'Callaghan uniosła & krzesła obrotowego. Ella O’Callaghan uniosła głowę na \\
\hline $\begin{array}{l}\text { głowę na tyle, by spojrzeć mu prosto w oczy i wycedziła } \\
\text { pewnym tonem: }\end{array}$ & $\begin{array}{l}\text { tyle, by spojrzeć mu prosto w oczy i powiedziała powoli, } \\
\text { mocnym i spokojnym głosem: }\end{array}$ \\
\hline $\begin{array}{l}\text { - Więc co mam zrobić? Zacząć się sprzedawać, panie } \\
\text { O’Doherty? }\end{array}$ & $\begin{array}{l}\text { - I co niby mam zrobić, panie O’Doherty, zostać } \\
\text { prostytutką? }\end{array}$ \\
\hline - Nie ma potrzeby tak się unosić, panno O’Callaghan. & $\begin{array}{l}\text { - Ależ panno O’Callaghan, nie musi pani reagować w } \\
\text { ten sposób. }\end{array}$ \\
\hline
\end{tabular}


- Nie ma potrzeby grozić mi wyrzuceniem mnie z domu. Nie pozwolę na to. Roscarbury Hall to całe moje życie. Nie dam go sobie odebrać.

- Może posiada pani coś, co można spieniężyć?

- Na przykład okazałą kolekcję klejnotów?

Peter O’Doherty zerwał się z miejsca, ze zniecierpliwieniem pobrzękując pękiem kluczy.

- Proszę iść do domu, zastanowić się i wrócić tu w przyszłym tygodniu z jakimś planem spłaty.

Wyciągnął rękę do Elli, ale zignorowała go.

- Nigdy w swoim pobożnym życiu nie czułam się, tak jak teraz: jakby mnie przybijano do krzyża. Prędzej umrę, niż wyprowadzę się z Roscarbury Hall.

Jeśli O’Doherty zamierzał odpowiedzieć, nie dała mu na to szansy, bo wyszła z jego biura, trzaskając drzwiami. Co go obchodziło jakieś Roscarbury, stary dom, który chronił jej rodzinę w ciężkich czasach i jedyne miejsce, gdzie czuła się bezpiecznie? Zimą w pokojach było tak zimno, że aż widziało się własny oddech, schody na poddasze skrzypiały upiornie, a rygle okienne nieustannie pobrzękiwały, poruszane chłodnymi podmuchami wiatru. Pofałdowany teren parku opadał w kierunku jeziora, więc rolnik Sheehy nie mógł równo skosić trawnika; zbrązowiałe, rozmokłe kwiaty wiśni i liście opadłe z dębów i starych kasztanowców co roku zapychały strumyki.

Roscarbury istniało dla letnich zmierzchów, kiedy dom wypełniało ciepłe powietrze, a do kur wychodziło się tylnym wyjściem, aby zagonić je do kurnika. Każdego ranka Ellę budziło ćwierkanie szpaków, obsiadających przekrzywioną antenę telewizyjną, przymocowaną do komina. Siedzące na jodłach wrony i gołębie paskudziły na kamienne płyty otaczające fontannę, więc raz w miesiącu musiała je szorować. Owoców z zarośniętego ogrodu starczało na wypieki przez całe lato, a podczas fali upałów dojrzewały soczyste gruszki. Ella nigdy nie mogłaby opuścić Roscarbury: mgiełka przeszłości spowijająca ten stary dom otulała ją i napełniała spokojem.
- A pan nie musi grozić, że wyrzucicie mnie z domu. Nie dopuszczę do tego. Roscarbury Hall to moje życie. Nie pozwolę, by ktoś mi je odebrał.

- Może mogłaby pani coś sprzedać, by zdobyć potrzebną sumę?

- Zapewne ma pan na myśli moją ogromną kolekcję biżuterii.

Peter O’Doherty zerwał się z miejsca, niecierpliwie obracając w palcach pęk kluczy.

- Proszę po powrocie do domu spokojnie wszystko przemyśleć. Zapraszam w przyszłym tygodniu z planem spłaty zadłużenia.

Wyciągnął rękę, lecz Ella ją zignorowała.

- W całym swoim pobożnym życiu jeszcze nigdy nie musiałam dźwigać takiego krzyża. Szybciej umrę, niż wyniosę się z Roscarbury Hall.

Nawet jeśli O’Doherty chciał coś powiedzieć, nie dała mu na to szansy, wypadła z biura i trzasnęła drzwiami. Co go w ogóle obchodziło Roscarbury, co on wiedział o tym starym domu, który w trudnych chwilach brał mieszkańców w objęcia, o jedynym miejscu, w którym czuła się bezpiecznie? Zimą w pomieszczeniach panowały takie temperatury, że oddech zmieniał się w parę, schody na strych jęczały jak dusza potępiona, lodowate wiatry grzechotały ryglami przy oknach, czyniąc nieustanny hałas. Teren wokół domu falował i opadał w kierunku jeziora, przez co Sheehy nie mógł porządnie przejechać kosiarką, kamienne kanały rozprowadzające wodę po ogrodzie zatykały się co roku, i to długo po tym, jak kwiaty wiśni zdążyły zbrązowieć i rozmoknąć, a dęby i stare kasztanowce zgubić wszystkie liście.

Roscarbury istniało dla znużonych letnich dni pełnych słońca, kiedy ciepłe powietrze zalegało we wnętrzach i trzeba było przeganiać kury zaglądające do środka przez otwarte drzwi na tyłach domu. Każdego ranka budziło Ellę trajkotanie szpaków, które gromadziły się na rozchwierutanej antenie telewizyjnej przyczepionej do komina. Gołębie i wrony urzędujące w jodłach niszczyły kamienne płyty wokół fontanny, musiała skrobać je do czysta raz w miesiącu. Zarośnięty ogród przez całe lato dawał owoce na ciasta i soczyste gruszki w okresie największych upałów. Ella za nic nie potrafiłaby opuścić Roscarbury: mgły przeszłości spowijające ten stary dom otulały ją i napełniały spokojem. 
Dla Petera O’Doherty'ego nie miałoby to znaczenia, nawet gdyby mu o tym opowiedziała. Ella O'Callaghan razem $\mathrm{z}$ jej zapuszczonym domem była jedynie drobnym utrapieniem $\mathrm{w}$ jego napiętym harmonogramie dnia.
Petera O’Doherty, nawet gdyby mu o tym wszystkim opowiedziała, w ogóle by to nie obeszło. Ella O'Callaghan i jej popadający w ruinę dom stanowiły co najwyżej błahy i przykry przerywnik w rozkładzie pracowitego dnia.

Table 1. Two versions of translation

Building on Stolze (2011), the author of this paper selected three aspects which were then put to a deeper analysis, namely, the situative background, the discourse field, and the meaning dimension.

\section{Situative background}

A thorough analysis of the situative background, whose main objective is to activate a sort of 'reflected subjectivity' (Stolze 2011: 105) in a reader, brings in an association with Roscarbury as an old crumbling mansion in Ireland. This impression is crucial here because it influences the way that the above fragment is read and interpreted by a translator. The first associations are strengthened by the next lines of the fragment. A picture of a mansion, an old house surrounded by a kitchen garden, lots of trees and birds, provides the reader with initial orientation, certain content expectations as well as background fore-knowledge. The results obtained by means of the analysis of situative background might serve as further points of reference in the evaluation of a given rendering and guide a critic in the process of the interpretation of the adequacy of a translator's strategy.

As mentioned, the fragment to be analyzed comes from a novel entitled The Ballroom's Café by Ann O'Loughlin. The book was published in 2015 by Black and White Publishing. According to the description found on the back cover, the novel is about two elderly sisters, Ella and Roberta O'Callaghan, who live alone in an old mansion called Roscarbury Hall, situated in a small Irish village. The sisters, who are in conflict with one another, communicate only by means of notes. However, due to the fact that the women are threatened with bankruptcy, one of them decides to improve the financial situation and keep the mansion. As a result, Roscarbury's old ballroom is transformed into a café which is to bring in earnings in the near future.

The above description is the basic background knowledge that a translation critic should be equipped with before making an attempt to evaluate the target text. Naturally, a critic might broaden their knowledge by discovering the details of the plot. Deeper analysis of Internet sources reveals that the book is a debut novel about forced illegal adoption of children of unmarried mothers from Ireland to the US. This information is very important with regard to the translation scholar's first encounter with the source text. Building on them, he/she will is able to interpret possible realia (Stolze 2011: 248) as set within the source culture and to focus his/her imagination on rural areas of Ireland. Even such a short fragment as the one given above consists of the following source culture indications: "Roscarbury", "kitchen garden", "tarts", which help to position the text within the cultural and geographical dimensions of the source culture. Besides, they automatically arouse imaginative constructs which are to be exclusively focused on Ireland and Roscarbury. (For 
instance, 'kitchen gardens', especially the walled ones, have immense significance for the history of Ireland.) The above-mentioned initial constructs as cognitively present in a translation scholar's mind enable him/her to understand the whole message on the basis of its parts, and vice versa (see Gadamer 1960: 270-305).

With the 'positioning' of the text within the situative background, a translation scholar's cognitive landscape, including some connotations concerning possible personal experience, ${ }^{27}$ the knowledge base (as well as the hermeneutic circle) is activated, which, in turn, makes it possible for a grounded understanding of the source message to take place. Here it is worth referring to Heidegger (1962: 191) who once wrote that understanding always takes place from a specific vantage point. The understanding, however, is invariably connected with the process of interpretation which is grounded in what an interpreter already knows about a given situation. Therefore, developing an understanding of the source text on the basis of so-called 'fore-knowledge' might be accessed by a researcher through the hermeneutical analysis of the source text. Such analysis helps to discover those elements in the source text which should be prioritized by a translator. However, in order to acquire the understanding, the researcher has to be open to the message being transferred by the text itself. In other words, a translation critic cannot simply search for translation errors and possible divergences between the source and target texts, but he/she should concentrate on the shape of the final product as it relates to the context in which the product occurs (see also Brzozowski 2011: 7-9). It is worth noting how Gadamer (1990: 269) viewed the processes:

A person trying to understand something will not resign himself from the start to relying on his own accidental fore-meanings, ignoring as consistently and stubbornly as possible the actual meaning of the text until the latter becomes so persistently audible that it breaks through what the interpreter imagines it to be. Rather a person trying to understand a text is prepared for it to tell him something ... But this kind of sensitivity involves neither neutrality with respect to content nor the extinction of one's self but the foregrounding and appropriation of one's own fore-meanings and prejudices. The important thing is to be aware of one's own bias, so that the text can present itself in all its otherness and thus assert its own truth against one's own fore-meanings.

\section{Discourse field}

The next stage of the so called 'hermeneutical analysis' is the discourse field, determined by the ideological background of the source text, an author's social setting as well as a particular field of communication (Stolze 2011: 114). The main aim of this phase is usually to become familiarized with biographical data relating to the author in order to discover any possible interrelations

27 It is the knowledge about our familiar world that people start with when attempting to understand something, be it a text or human relations. Only by having a specific knowledge and experience base is it possible to launch the hermeneutic circle consisting in adding new information into the 'stable' knowledge base that is already cognitively stored in people's minds. In other words, it is necessary to have specific pre-understanding connected with a particular theme in order to understand a new input. 
between a particular text and the place of ideology. The author of The Ballroom's Café, a leading Irish journalist who has been working for many prestigious Irish newspapers for about thirty years now, is a relatively unknown Irish author of women's fiction. In her professional work, Ann O'Loughlin has dealt with the reporting of controversial issues about human existence. Despite a relative lack of experience in writing fiction, her novel, much to the author's surprise, hit Amazon. co.uk's top 20 bestselling ebooks of 2015. As for the genre, this is an example of a modern women's fiction novel mostly oriented towards a female readership. Due to the fact that the whole story is set in a small Irish village, close attention should be devoted to all possible layers of particular elements of Irish culture. The author of this paper is of the opinion that reading the whole source text by a translation critic is not only an option but a necessity. Only by reading the entire text is he/she able to identify the elements of the discourse field properly. In the case of the novel, at this point a researcher should be cognitively oriented towards Ireland and the milieu of women who had participated inadvertently in clandestine and illegal adoptions of Irish children by U.S. families.

\section{Meaning dimension}

Every discourse field is reflected in the meaning dimension which is the third stage of the hermeneutical analysis of the source and target texts. Stolze (2011: 116), defining the concept, refers to cognitive linguistics and writes, “... meaning dimension ... recurs in the texts, reflecting in cultural associations, specific metaphors, key words, image schemas, and terminology to be found in a text." The author, building on Schleiermacher, goes on to describe the function of the title or the opening of a text. She defines it as "a clue for understanding", setting the general theme (ibid), because what is understood in the process of reading is actually reflected in the structure of the text, especially in the key words which are recognized holistically by searching for an "isotopic semantic network of significant appearance, where concept appear surrounded by neighbouring synonyms and in repetition of the same words." (Stolze 2011: 117)

Isotopic networks are identified on the basis of the recurrence of particular lexemes and the lexical items that surround them. Both the front cover and the title of the novel arouse specific associations that correspond to the emotional sphere of the target readers. The Ballroom's Café evokes connotations such as nostalgia, memories, deep emotions, love, joy, sadness, secrets, and conversations. Also, the first line of the novel: Rathsorney, Co. Wicklow, March 2008 conjures certain images in the reader's mind: Ireland, a county, a particular geographical location, which guides the reader cognitively towards Ireland. The associations could be best depicted by a semantic network of connected lexemes and their meaning. In the novel in question we might distinguish three "impressionistic sketches" (Stolze 2011: 119), which create further scenes for the target readership. (The sketches could also be called the "lexical fields" (ibid) emerging in the course of reading the source text.) By analyzing the semantic networks, a translation critic is able to evaluate whether the semantic dimension of a target text is close to the original one. The three 'sketches' mentioned above (fight, the mansion, and cultural background) are presented in the table below. 


\begin{tabular}{|c|c|c|}
\hline Fight & The mansion & Cultural background \\
\hline $\begin{array}{l}\text { bosses } \\
\text { effort } \\
\text { paying the loan } \\
\text { to take steps } \\
\text { to get our money back } \\
\text { prostitute } \\
\text { look... straight in the eye } \\
\text { threaten } \\
\text { push me out of my home } \\
\text { jumped to his feet } \\
\text { impatiently fingering } \\
\text { plan of repayment } \\
\text { prayerful like } \\
\text { crucified } \\
\text { banging the door }\end{array}$ & $\begin{array}{l}\text { Roscarbury Hall } \\
\text { extensive jewel collection } \\
\text { old house } \\
\text { bad times } \\
\text { felt safe } \\
\text { banshee } \\
\text { constant tapping } \\
\text { rills silted up } \\
\text { cherry blossom flowers } \\
\text { oak } \\
\text { old horse chestnut trees } \\
\text { worn days } \\
\text { summer sun } \\
\text { warm air } \\
\text { hens } \\
\text { starlings } \\
\text { crows } \\
\text { pigeons } \\
\text { stone slabs } \\
\text { fountain } \\
\text { overgrown kitchen garden } \\
\text { fruit } \\
\text { luscious pears } \\
\text { hot spell } \\
\text { mists of the past }\end{array}$ & $\begin{array}{l}\text { Rathsorney, Wicklow } \\
\text { O'Callaghan } \\
\text { O’Doherty } \\
\text { banshee } \\
\text { kitchen garden } \\
\text { tarts }\end{array}$ \\
\hline
\end{tabular}

Table 2. Lexical sketches creating the semantic framework of the novel (on the basis of the sample)

The first lines of the text (Rathsorney, Co. Wicklow, March 2008; a typical Irish surname) are immediately interpreted in cultural terms, with regard to Ireland and Irish culture. Indeed, it is Ireland which, albeit indirectly, becomes the constant theme of the entire source text in regard not only to the cultural references but also to the complex social issues (illegal adoptions) depicted in the text. According to Stolze (2011: 119-120), the semantic network represents the primary semantic content of the text, which is a key to understanding. Let us reiterate, however, that the understanding is built on lexical inferences.

It is beyond the scope of this paper to describe the three fields given above in much detail; however, it might be concluded that the recurring theme in the whole text is Roscarbury Hall which, 
to some extent, becomes one of the main protagonists of the story, positioned in the center of the narrative alongside two elderly sisters. Equally important are thematic strings related to religious connotations ('In all my prayerful life, I have never felt so crucified') as well as sensual key words evoking an ethereal and romantic sphere ('luscious', 'hot', 'spell'). Roscarbury Hall is presented by means of a dual set of images: one description is full of regret, sadness, disappointment, and even death (words depicting devastation and destruction of the building, the reference to a 'banshee'), the other evokes nostalgic memories about the past, feelings of safety and comfort, liveliness as well as the pure joy that the house brings to one of the female protagonists.

After having analyzed the meaning dimension a researcher should then focus on the predicative mode, namely, the precision of translation, the rendition of a particular point of view and deixis. In the opinion of the author of this article, at this point the precise tools of cognitive analysis as developed by Tabakowska (2015), built on cognitive grammar (Langacker 2013), could be employed. In this case a cognitive analysis of the description of the Rosarbury Hall (the vantage point) as well as the aspect of iconicity would be particularly revealing.

\section{Translators' Approaches}

As mentioned, only by taking into account the phenomenological perspective of a translator in the translation process is a translation scholar able to evaluate the nature of any marked divergences between the message in the source language and within the target language, and specify the reason for such divergences, which do not always have to be regarded as translation inadequacy. The author of the article argues that any translation criticism is complete if and only if it is accompanied by a detailed account of a translator's approach, as seen from the translator's perspective (obtained, e.g., via interviews conducted with translators, introspection and retrospection techniques or so called translation diaries). In what follows, the phenomenological accounts of translational processes are presented, from the perspective of the two translators taking part in the study, who provided comments on the translation process by means of Integrated Problem and Decision Reporting research tool.

In Table 3 below, the two translators' accounts are presented. 


\begin{tabular}{|c|c|}
\hline The first account & The second account \\
\hline $\begin{array}{l}\text { I was translating a fragment of the text. I translated some } \\
\text { of the sentences, or their parts, in a preliminary way, } \\
\text { stressing the adequacy and marking some fragments } \\
\text { which were to be modified later. } \\
\text { I verified and corrected the fragment that I had trans- } \\
\text { lated; however, this time, I paid attention to cohesion and } \\
\text { fluency of the target text. } \\
\text { Then, I read the target text a few times, at different inter- } \\
\text { vals, filling in and polishing up the translation. } \\
\text { (In practice, the whole process occurs much faster and in } \\
\text { a more efficient way than one might think on the basis of } \\
\text { the above description... ) } \\
\text { I really liked the description of the old house, suggestive } \\
\text { vocabulary rendering the atmosphere in the building and } \\
\text { accentuating the emotions of the heroines, with regard } \\
\text { not only to the past (nostalgia) but also to the present } \\
\text { times (frustration). } \\
\text { When I translate, I usually do my best in order to make } \\
\text { the target text fluent and cohesive- the text which sounds } \\
\text { right and reads well. The achievement of such an effect } \\
\text { sometimes requires lots of trials and stylistic modifica- } \\
\text { tions; however, I was satisfied, in the majority of cases, } \\
\text { with what I had achieved. }\end{array}$ & $\begin{array}{l}\text { The text itself did not pose any serious translation prob- } \\
\text { lems. It is a simple narration, written in a nice and prop- } \\
\text { er style. I did my best to maintain the rhythm and the } \\
\text { mood of the source text. I usually work within the area of } \\
\text { a sentence (probably I connected two sentences into one } \\
\text { only once). } \\
\text { In the case of more challenging fragments, when I deal } \\
\text { with the first draft of translation, I usually immediately } \\
\text { jot down various translation solutions, a few versions, } \\
\text { and only then do I polish the text up, search for the most } \\
\text { adequate synonyms, and choose the best solution, which } \\
\text { sometimes requires a repeated revision. } \\
\text { Emotions? The translation process is always accompa- } \\
\text { nied by a feeling of loss and by irritation, usually in its } \\
\text { two facets. The first is the question of foreignization and } \\
\text { a cultural context. Therefore, I was at pains to have had } \\
\text { changed 'banshee' into 'dusza potepiona', which, surely, } \\
\text { makes the reference to folklore disappear, but, in the } \\
\text { Polish version, such an element would sound much more } \\
\text { exotic than in the source text. However, if such elements } \\
\text { would appear in the text more often, I would surely em- } \\
\text { phasis them in some way. The second is the question of } \\
\text { clarity and brevity of some languages (e.g. English), which } \\
\text { are impossible to be translated into rough Polish. And so } \\
\text { lovely "baking her worries away" was lost. }\end{array}$ \\
\hline
\end{tabular}

Table 3. The translators' accounts

The above accounts reveal what was going on in the translators' minds during the translation process. The author of this paper claims (as specified in the opening sections of the text) that any evaluation of a translation product should be accompanied by a detailed analysis of the translator's account, a description of his/her translation decisions, translation strategies and techniques, translation tools as well as his/her emotions accompanying the whole process and attitude towards both the source and the target texts. The author also argues that such a qualitative analysis of both the translation product and the translator's approach might reveal valuable information about the translation process and the relationship between the target text and the translator.

The accounts illustrate interesting - and still under-researched - aspects of how translators address translation problems, prepare for the translation process, and view their own role in the publishing process. Furthermore, the methodology presented in the article provides translation scholars as well as translation critics with an effective tool (albeit by no means objective, because there simply cannot be any objectivization in the evaluation of both translation products and translation processes) which makes it possible to collect valuable data relating to various dimensions of the act of translation. 
The scope of the article intentionally restricts the author to discussing only selected issues as identified in the above accounts; however, the data might be interpreted in a number of different ways. Due to the fact that the article is of an exemplary nature, the author decided to focus on one of the dimensions in the translators' accounts, which might help to explain why the translators adopted particular translation strategies. Let us take as an example the question of domestication versus foreignization - central key notions in translation studies, which held sway throughout the $20^{\text {th }}$ and $21^{\text {st }}$ centuries. The notions go back in the history of translation theory to Friedrich Schleiermacher (1992: 41-2), who considered two approaches to be adopted by a translator:

Either the translator leaves the writer alone as much as possible and moves the reader towards the writer, or he leaves the reader alone as much as possible and moves the writer toward the reader.

The above words exerted an enormous influence on the representatives of modern translation theory, especially on Venuti's ideas of 'foreignization' and domestication' (Venuti 1995: 19-21), which are to serve as points of reference in the discussion of the translators' accounts given above.

Both translators indicated their inclination towards 'polishing the target text up'. Let us quote the first translator's words: "When I translate, I usually do my best in order to make the target text fluent and cohesive - a text which sounds right and reads well." The second translator also stressed the need for domestication: "I was at pain to change 'banshee' into 'dusza potępiona', which, surely, makes the reference to folklore disappear, but in the Polish version such an element would sound much more exotic than it does in the source text." Such an approach might be interpreted in terms of 'invisibility' of the translator, the central notion of modern translation theory. Invisibility has been described by Venuti (1995) as the situation in which translators stick to so called 'fluent' translation of the source text with the aim of producing an idiomatic text. Venuti rightly underlines that the situation is affected by publishers' and readers' expectations towards the style and shape of the target text.

A translated text, whether prose or poetry, fiction or non-fiction, is judged acceptable by most publishers, reviewers and readers when it reads fluently, when the absence of any linguistic or stylistic peculiarities makes it seem transparent, giving the appearance that it reflects the foreign writer's personality or intention or the essential meaning of the foreign text - the appearance, in other words, that the translation is not in fact a translation, but the 'original' (Venuti: 1995: 1).

The obvious conclusion, then, is that the translators who participated in the study aimed at maintaining dynamic equivalence (see Nida 1964: 159) or, in other words, a covert translation (see House 1997: 69). The style of translating was 'invisible' (Venuti 1995: 1).

The strategy is usually due to publishers' expectations of the shape of the target text, which, to a considerable extent, is driven by marketing reasons. In a wider context, it might be concluded that the adoption of the strategy of domestication is the direct result of post-colonialism, hegemonic norms, and globalization: 
A publishing industry that repeatedly issues fluent, domesticating translations of the latest American bestsellers - written in the standard dialect of the official language - encourages uncritical consumption of hegemonic values while maintaining current asymmetries in cross-cultural exchange (Venuti 1998: 188).

The question that consequently arises here is that of translation ethics; however, the scope of the article restricts the author only to stressing the need for further research on the theme.

The translation strategies applied by the two translators in question undoubtedly point to the domestication philosophy. It can be seen in regard not only to their rationale behind the decisions that they had made but also to the concrete translation solutions that they had adopted when translating, for instance, the item 'kitchen garden'. As can be observed in the translation samples, 'kitchen garden' was rendered by the two translators as 'ogród'. However, the analysis of both the situated background of the item as well as its meaning dimensions indicates a necessity of taking into consideration the full meaning of the item as related to its cultural framework. As mentioned in one of the previous sections of this article, 'kitchen gardens' constitute a very important element of Irish culture and history; therefore, it might be surprising that none of the two translators took it into consideration, although it is clear from their accounts that they were fully cognizant of the situative background of the source text as well as of the presence of cultural references. The divergence might be partially explained by turning to the hermeneutic category of discourse field. Clearly, none of the translators analyzed this aspect in detail. It might be assumed that if the translators had checked Ann O'Loughlin's idea behind the novel in question (especially its references to illegal adoptions of Irish children), they would have made different translation decisions and would certainly conclude that in this case the procedure of adaptation of cultural references to the potential expectations of a target readership is not a proper solution. On the basis of the conclusions presented above it also seems valid to suggest that the two translators did not analyze the semantic network of the sample, which undoubtedly indicates a strong connection between the plot and Irish culture ('banshee', 'tart', 'kitchen garden', 'county', 'O'Callaghan', etc.).

The analysis of the accounts demonstrates that the translators consciously used domestication strategy so that the target text would be more fluent and transparent. By adopting the strategy and devoting much attention to the functional aspects of the renderings, both translators tried to satisfy the publisher's need for a highly readable and idiomatic translation. Due to the fact that recently there has been a strong tendency towards publishing so called 'bestsellers' within the Polish publishing industry, the owners of publishing houses as well as managing editors and editors-inchief have made deliberate attempts to publish books which are guaranteed to generate substantial profits as well as to dictate the translation methods which should be adopted in a particular case. The author of this paper sees the main factor for this as being the political, ideological, and cultural agenda of the translation and publishing processes. Publishers usually purchase translation rights mostly to those titles which have already achieved bestseller status abroad, particularly in the United States and in the United Kingdom, which is also the reason why translators are expected to provide a final product that purports to be an original and not a translation. 


\section{Conclusions}

It is worth asking the same questions here which Tabakowska asked when ending her article: "Was the whole thing really worthwhile? Would it not be enough just to read the ST and the TT in order to realize that the Polish translation is not an adequate rendering of the original?" (2000: 94). The author of this article claims that the whole thing which was described above was undoubtedly worthwhile. Firstly, the suggested way for the analysis of both translation products and translators' approaches helps to evaluate the translational process considered a result of a specific relationship between a text and a translator (a reader). Secondly, the presented approach, encompassing a variety of different perspectives (cognitive, hermeneutical and phenomenological), makes it possible for a translation scholar to refrain from undertaking a purely linguistic or grammatical analysis (too often perceived as 'objective') and to adopt a more holistic strategy in the process of evaluating translation products. Thirdly and finally, it is no longer valid to call a particular rendering adequate or inadequate unless a given translator's account and the way the target text is embedded in a cultural and historical context, including publishers' philosophy, are taken into consideration. This contribution should be regarded as a prolegomenon to a more comprehensive study of the ways phenomenological evaluations of translations are conducted, which can only be performed by taking into consideration the importance of the inevitable 'subjectivity' element present in every text.

\section{REFERENCES}

Brzozowski, Jerzy. 2011. Stanąć po stronie tłumacza. Zarys poetyki opisowej przekładu. Kraków: Wydawnictwo Uniwersytetu Jagiellońskiego.

Cercel, Larisa, John Stanley \& Radegundis Stolze. 2015. Hermeneutics as a Research Paradigm. In: Cercel, Larisa, John Stanley and Radegundis Stolze (eds.), Translational Hermeneutics. The First Symposium, 17-40. Zeta Books: Bucarest.

Gadamer, Hans-George. 1960. Wahrheit und Methode. Grundzüge einer philosophischen Hermeneutik. Tübingen: J.C.B. Mohr.

Gadamer, Hans-George. 1990. Truth and Method. New York: Crossroad.

Gallagher, Shaun. 2004. Hermeneutics and the Cognitive Sciences. Journal of Consciousness Studies 11. 162-174.

Heidegger, Martin. 1962. Being and Time. London: SCM Press Ltd.

House, Juliane. 1997. A Model for Translation Quality Assessment. Tübingen: Gunter Narr.

Iser, Wolfgang. 1978. The Act of Reading. A Theory of Aesthetic Response. Baltimore/London: John Hopkins University Press.

Langacker, Ronald W. 2013. Essentials of Cognitive Grammar. Oxford/New York: Oxford University Press.

Nida, Eugene. 1964. Towards a Science of Translating. With Special Reference to Principles and Procedures Involved in Bible Translating. Leiden: E. J. Brill.

O’Loughlin, Ann. 2015. The Ballroom Café. Edinburgh: Black \& White Publishing. 
Schleiermacher, Friedrich. 1997. On the different methods of translating. In: Schulte, Rainer \& John Biguenet (eds.), Theories of Translation. An Anthology of Essays from Dryden to Derrida, 36-54. Chicago: The University of Chicago Press.

Stolze, Radegundis. 2011. The Translator's Approach - Introduction to Translational Hermeneutics. Theory and Examples from Practice. Berlin: Frank \& Timme.

Tabakowska, Elżbieta. 2000. Is (Cognitive) Linguistics of any Use for (Literary) Translation? In: Tirkkonen-Condit, Sonja \& Riitta Jääskeläinen (eds.), Tapping and Mapping the Processes of Translation and Interpreting. Outlooks on Empirical Research, 83-95. Amsterdam/Philadelphia: John Benjamins.

Tabakowska, Elżbieta. 2015. Myśl językoznawcza z myśla o przekładzie. Wybór prac. Kraków: Wydawnictwo Uniwersytetu Jagiellońskiego.

Venuti, Lawrence. 1995. The Translator's Invisibility. A History of Translation. London/New York: Routledge.

Venuti, Lawrence. 1998. The Scandals of Translation: Towards an Ethics of Difference. London/New York: Routledge.

Wills, Wolfram. 1996. Knowledge and Skills in Translator Behaviour. Amsterdam/Philadelphia: John Benjamins.

Wittgenstein, Ludwig. 1953. Philosophische Untersuchungen: Kritisch-Genetische Edition. Frankfurt: Suhrkamp. 